\title{
SURGICAL TREATMENT OF LUMBAR DISC HERNIATION IN PREGNANT WOMEN: REPORT OF TWO CASES AND A SYSTEMATIC REVIEW
}

\author{
TRATAMENTO CIRÚRGICO DA HÉRNIA DE DISCO LOMBAR EM GESTANTES: RELATO DE \\ DOIS CASOS E REVISÃO SISTEMÁTICA
}

\section{TRATAMIENTO QUIRÚRGICO DE LA HERNIA DISCAL LUMBAR EN EMBARAZADAS: INFORME DE DOIS CASOS Y REVISIÓN SISTEMÁTICA} \author{
Andrei Vladimirovich Moskalev², Vadim Anatolevich ByvaltseV ${ }^{3}$ \\ 1. Novosibirsk Research Institute of Traumatology and Orthopaedics, Novosibirsk, Russia. \\ 2. Biostatistics and Clinical Trials Center, Novosibirsk, Russia. \\ 3. Irkutsk State Medical University, Irkutsk, Russia.
}

IAleksandr Vladimirovich Krutko ${ }^{1}$, Abdugafur Jabborovich Sanginov¹, Aleksey Vladimirovich Peleganchuk', Alina Anatolevna Alshevskaya ${ }^{2}$,

\begin{abstract}
Objective: To review the surgical treatment of lumbar disc herniation in pregnancy. Methods: We systematically reviewed cases of surgical treatment of pregnant patients with lumbar IVD herniations in accordance with the Cochrane Handbook for Systematic Reviews of Interventions. We searched on electronic databases, including PubMed, Scopus, and Google Scholar, to find relevant articles by keywords. Results: A literature review of 42 cases is presented. Conclusions: The authors' own data and the literature data demonstrate that decompression surgery in pregnancy is effective and safe for both mother and fetus; however, radical surgery (fusion) can lead to very adverse sequelae for the fetus. Level of Evidence III; Systematic review ${ }^{b}$ of Level III studies.
\end{abstract}

Keywords: Pregnancy; Hernia; Diskectomy; Cauda equina; Polyradiculopathy.

\section{RESUMO}

Objetivo: Nosso objetivo foi rever o tratamento cirúrgico da hérnia de disco lombar na gravidez. Métodos: Revimos sistematicamente os casos de tratamento cirúrgico de pacientes grávidas com hérnia lombar por DIV, de acordo com o Manual Cochrane para Revisões Sistemáticas de Intervenções. Procuramos, através de bases de dados eletrônicas, incluindo PubMed, Scopus e Google Scholar, encontrar artigos relevantes por palavras-chave. Resultados: Revisão da literatura de 42 casos foi apresentada. Conclusões: Os dados dos próprios autores e os dados da literatura demonstram que a cirurgia de descompressão na gravidez é eficaz e segura tanto para a mãe como para o feto. Entretanto, a cirurgia radical (fusão) pode levar à sequelas muito adversas para o feto. Nível de Evidência III; Revisão sistemáticab de Estudos de Nível III.

Descritores: Gravidez; Hérnia; Discotomia; Cauda equina; Polirradiculopatia.

\section{RESUMEN}

Objetivo: Nuestro objetivo fue revisar el tratamiento quirúrgico de la hernia de disco lumbar en el embarazo. Métodos: Revisamos sistemáticamente los casos de tratamiento quirúrgico de pacientes embarazadas con hernias de DIV lumbar de acuerdo con el Manual Cochrane para Revisiones Sistemáticas de Intervenciones. Realizamos búsquedas en bases de datos electrónicas, incluidas PubMed, Scopus y Google Scholar, para encontrar artículos relevantes por palabras clave. Resultados: Se presentó la revisión de la literatura de 42 casos. Conclusiones: Los propios datos de los autores y los datos de la literatura demuestran que la cirugía de descompresión en el embarazo es efectiva y segura tanto para la madre como para el feto; sin embargo, la cirugía radical (fusión) puede conducir a secuelas muy adversas para el feto. Nivel de Evidencia III; Revisión sistemáticab de Estudios de Nivel III.

Descriptores: Embarazo; Hernia; Discectomía; Cauda equina; Polirradiculopatía.

\section{INTRODUCTION}

Low back pain in combination with radicular syndromes occurs in more than $50 \%$ of pregnant females at more than 20 weeks of gestation. ${ }^{1}$ The development of lumbodynia is largely promoted by the biomechanical and hormonal changes typical of pregnancy. The biomechanical mechanism of back pain during pregnancy is associated with an increase in uterus size, an anterior shift of the center of gravity with a compensatory increase in lumbar lordosis, and an increased load on the lower lumbar spine. ${ }^{2}$ The hormonal mechanism is associated with the hormone relaxin, which reduces the tone and strength of the musculoskeletal apparatus of the pelvic region. However, the data on this relationship are controversial: although earlier studies have revealed high serum relaxin levels in pregnant females with low back pain, ${ }^{3}$ recent publications in this area have indicated an inadequate relationship between the serum relaxin level and the rate of lumbar and pelvic pain. ${ }^{4,5}$ Symptomatic lumbar intervertebral disc (IVD) herniation is far less common, approximately one case per 10,000 pregnant females. ${ }^{6}$ The risk 
factors for IVD herniation in pregnancy include age, obesity, physical activity, positive history, lumbodynia during menstruation, traumatic injuries, stress factors, male fetus, etc. ${ }^{1,7,8}$ In most cases, conservative treatment is sufficient to stop lumbar spine and lower limb pain caused by degenerative changes and herniation of the IVD. In the case of failed conservative treatment or a severe neurological deficit, surgical treatment is used. Publications in recent years have demonstrated the safety of spine surgery during pregnancy in the presence of a well-coordinated team consisting of a neurosurgeon, anesthesiologist, neurologist, and obstetrician-gynecologist, $8-17$ which is also confirmed by our experience. During preparation of this manuscript, two reviews of surgical treatment of herniated IVD in pregnant females were published. In an article by Ardaillon et al., 17 articles and 27 cases of microdiscectomy are analyzed. ${ }^{18}$ An article by Di Martino et al. reviewed 20 articles and 32 cases of microdiscectomy. ${ }^{19}$ However, a number of questions on the choice of optimal approach, time of surgery, and position during surgery are not fully resolved. The purpose of our study was to conduct a systematic review of surgical treatment for herniated IVD in pregnant females to summarize the existing opinions on controversial issues. This paper reviews 30 articles and 46 cases of microdiscectomy, including two cases of our own.

\section{METHODS}

This study obtained ethical approval from the Ethics Committee of Irkutsk State Medical University (118/2). All participants gave informed consent before taking part.

We systematically reviewed cases of surgical treatment of pregnant patients with lumbar IVD herniations in accordance with the Cochrane Handbook for Systematic Reviews of Interventions.

We also searched on electronic databases, including PubMed, Scopus, and Google Scholar to find relevant articles. The keywords used were 'pregnant', 'gravid', 'parturient', and 'parous' for pregnancy and 'disk'/'disc' and 'hernia' or 'discectomy'/'diskectomy' for discectomy and hernia of the IVD, as well as additional terms for concomitant conditions ('cauda equina syndrome', 'polyradiculopathy'). The search was performed on the electronic databases PubMed, Scopus, and Google Scholar. We limited the search to the English language, with a cut-off period of articles published between 1990 and 2017. The last search was done at the end of July, 2017. The searches were independently conducted by the three authors, and the list of relevant abstracts was collated. We identified additional case reports from the reference list of included studies. Unpublished and non-peer reviewed data were not considered.

The inclusion criteria were as follows: clinical cases (outcome studies, studies on adult pregnant females, case reports) describing surgical treatment of lumbar IVD herniation in pregnant females, provided that the symptoms developed during pregnancy, and the availability of full text. The exclusion criteria were as follows: studies written in a language other than English, successful therapeutic treatment, reviews, studies on animals and cadavers, in vitro studies, technical notes, letters to editors, and articles not specifically reporting outcomes. The three-level selection system was used for the final analysis of full-length articles.

Two authors independently extracted data using a standardized data extraction form. Disagreement was resolved by discussion or consensus with a third party. The corresponding author of a study was contacted to gather any missing information. Information was extracted using special tables designed for the study based on previous reviews. The tables contained the following variables: age, number of previous pregnancies and deliveries, gestational age of symptom onset, surgery time, complications, history of conservative treatment, anesthesia type, surgical position, lesion level, type of surgery, whether the surgery occurred after delivery (Cesarean), disappearance of symptoms during follow-up, and outcome of the pregnancy.

The data analysis focused on descriptive assessment of the extracted information. The small size of the total sample composed of individual case reports prevented statistical analysis using parametric tests and calculation of effect sizes. For this reason, the data are presented as a summary table for all patients. The general trends and patterns were revealed and analyzed.

In the period from $1^{\text {st }}$ January 2005 to $1^{\text {st }}$ December 2015, 67,388 patients with lumbar pains (including 38,087 patients with lumbar IVD herniations) were consulted at the Novosibirsk Research Institute of Traumatology and Orthopedics (NRITO). During the ten-year period, 9,376 patients underwent spine surgery for degenerative IVD disease. Of these, 5,174 patients underwent discectomy for IVD herniation. A total of 257 pregnant females with lumbar pain presented to the NRITO (mainly to determine the type of obstetrics). Of these, two patients underwent discectomy.

\section{RESULTS}

\section{Case reports}

Case 1. A 36-year-old patient B., second pregnancy, 20 weeks, presented with complaints of pains in the back and lower limbs, numbness in the anogenital region, legs, and feet, and decreased strength in the feet for at least three weeks. The pain intensity in the back and lower limbs was scored 9 by the Visual Analogue Scale (VAS), and 82 by the Oswestry Disability Index (ODI). Neurological status presented decreased strength in the lower limbs to three points, the absence of Achilles and plantar reflexes, hypoesthesia in the S1, S2, and S3 regions, and straight leg raise of $30^{\circ}$. The functions of the pelvic organs were not affected.

$\mathrm{MRI}$ examination revealed a L5/S1 herniated IVD on the right. (Figures 1A, 1B) Radiography was not performed due to the teratogenic effect. Because of urgent indications, the patient underwent a L5/S1 microdiscectomy on the right, being placed on her left side on the operating table. Epidural anesthesia was used. There were no intraoperative complications.

In the postoperative period, pain in the lower limbs and numbness in the anogenital area completely alleviated. The patient was discharged from the hospital on the sixth day. Strength and sensitivity in the lower limbs recovered after two weeks. Some minor pain remained in the wound area.

The patient gave birth to a girl at 39 weeks of gestation. The delivery was natural, without complications.

One year after surgery, the patient complained of moderate pain in the right gluteal region (a VAS score of 2). The disability index was 8 (ODI). Figures $2 \mathrm{~A}$ and 2B show control MRI scans.

The patient again presented to the hospital after 1 month with worsening of pain in the lumbar spine (VAS score of 5) and left lower limb (VAS score of 9) and numbness on the outer surface of the left thigh; the ODI at the time of examination was 78. Weakness of the left foot extensors (a score of 4 ) and decreased sensitivity in

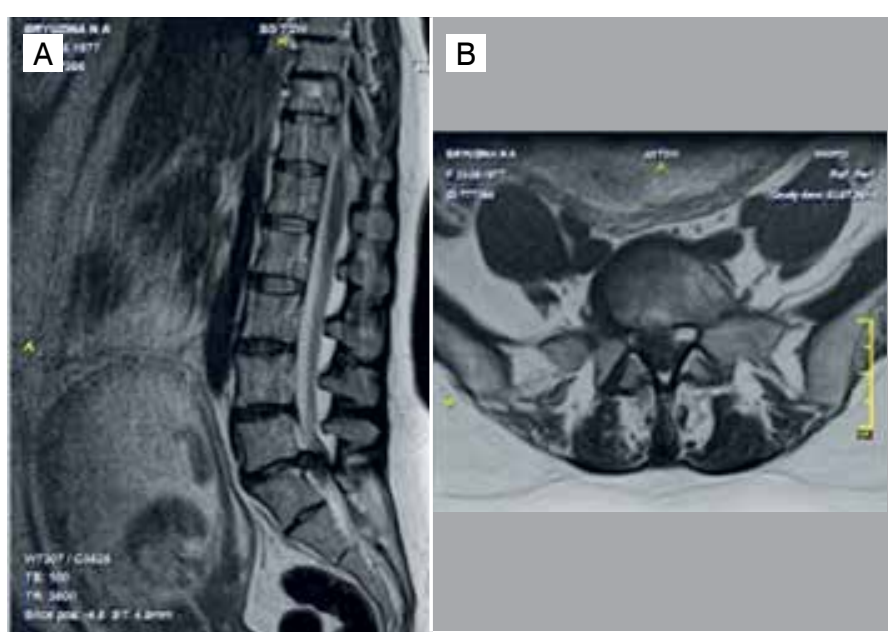

Figure 1. MRI before surgery (L5-S1 LDH). Sagittal (A) and axial (B) planes. 


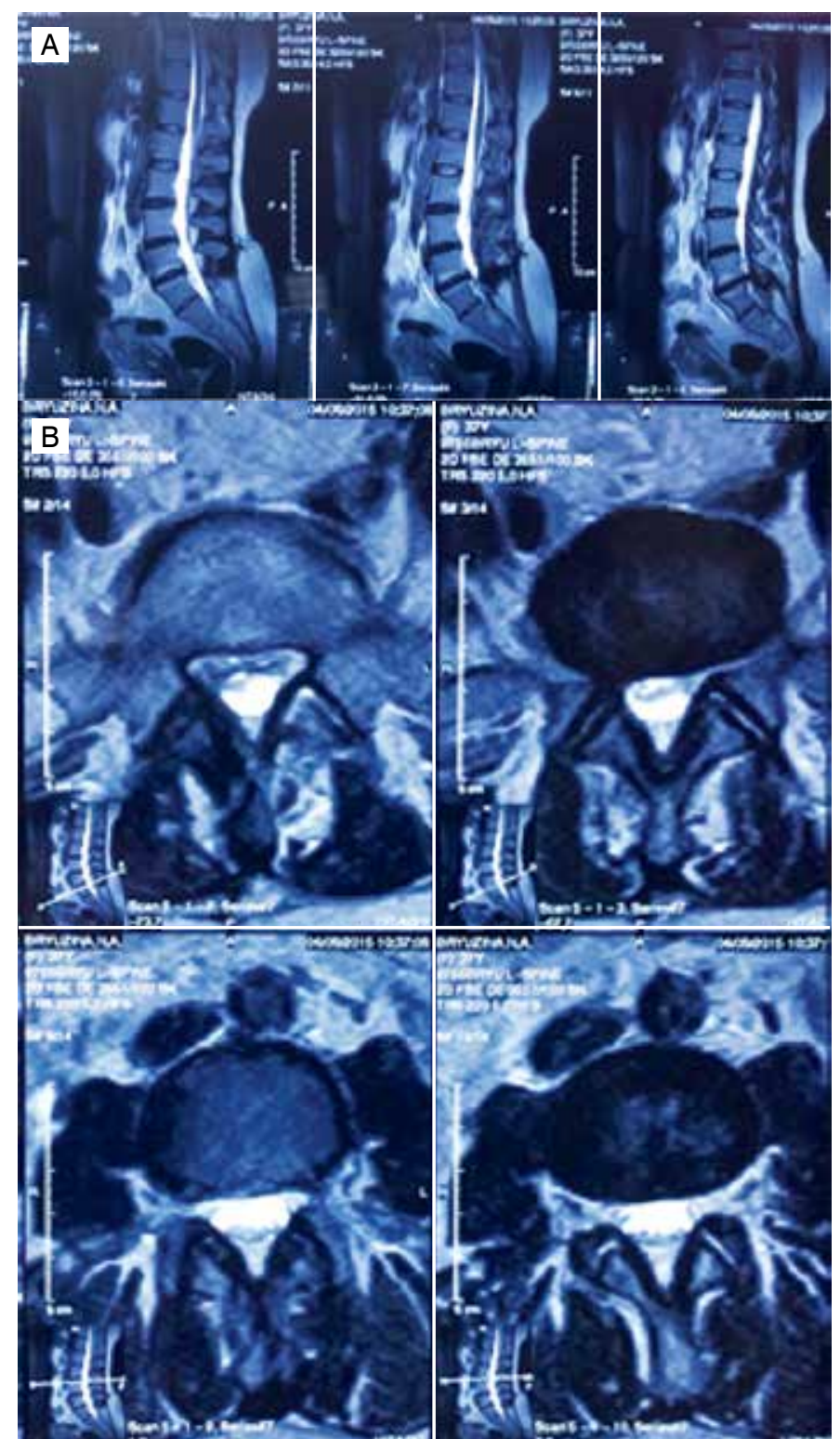

Figure 2. A. MRI, 1 year after surgery. Sagittal plane; B. MRI, 1 year after surgery. Axial plane.

the left S1 area were detected. The functions of the pelvic organs were not affected.

$M R I$ revealed L4/L5 lumbar IVD herniation (Figures 3A, 3B); there were postoperative changes at the L5/S1 level on the right. The patient underwent elective surgery: a L4/L5 microdiscectomy on the left and dynamic interspinous fixation at the L4/L5 level using a DIAM implant.

Immediately after surgery, the lower limb pain stopped (a VAS score of 0 ), and the strength recovered. Sensation disorders were not detected. On the sixth day after surgery, the patient was discharged to follow-up by a local neurologist.

Case 2. A 31-year-old patient R., second pregnancy, 16 weeks. The first delivery was natural, without complications. The patient presented with intense pain in the lumbar spine and outer surface of the left lower limb. The pain led to walking problems. During the last four weeks, the patient reported worsening of lumbar pain. Severe pain in the left lower limb developed one week ago. Therapy had no effect. The lower limb pain was scored 8 (VAS), and the back pain was scored 8 (VAS). The ODI was 78.

Straight leg raise symptoms and hypoesthesia in the left S1 area were revealed.
MRI findings were as follows: a L5/S1 herniated IVD on the left, L5 retrolisthesis, and a median protrusion of the L4/L5 IVD (Figures 4A, 4B). Radiography was not performed due to the teratogenic effect.

The patient underwent an elective microdiscectomy at the L5/S1 level on the left. The patient was in the right lateral position on the operating table. Epidural anesthesia was used. There were no complications to the fetus.

After surgery, the lower limb pain completely alleviated, and the area of hypoesthesia decreased.

The patient was discharged from the hospital on the seventh day after surgery. The patient gave birth to a girl at 38 weeks of gestation. The baby was delivered by Cesarean section.

A follow-up examination 10 months after surgery revealed moderate discomfort in the lumbar region (a VAS score of 2 for the spine and a VAS score of 1 for the lower limb). The ODI was 12. According to the patient, her spine did not interfere with her care of the child (hold the baby in her arms, walk, etc.).

Control MRI of the lumbar spine (Figures 5A, 5B) showed the condition after removal of the L5/S1 IVD herniation; recurrent median L5/S1 IVD herniation with left-sided lateralization, which caused stenosis of the lateral recess of the spinal canal; L5 retrolisthesis; median protrusion of the L4/L5 IVD; and Modic type I degenerative changes in adjacent parts of the L5 and S1 bodies.

Given the minimal clinical manifestations of recurrent IVD herniation, it was decided to postpone surgical treatment. Potential future surgery for this patient would include $360^{\circ}$ circular fusion (screw and interbody fusion of the segment).

\section{Systematic review}

A combined search of the databases and an analysis of references yielded 2,542 articles in the databases. We excluded 343 articles published before 1990, and 2,042 papers regarded as irrelevant, i.e. those that described other conditions of the mother/fetus,

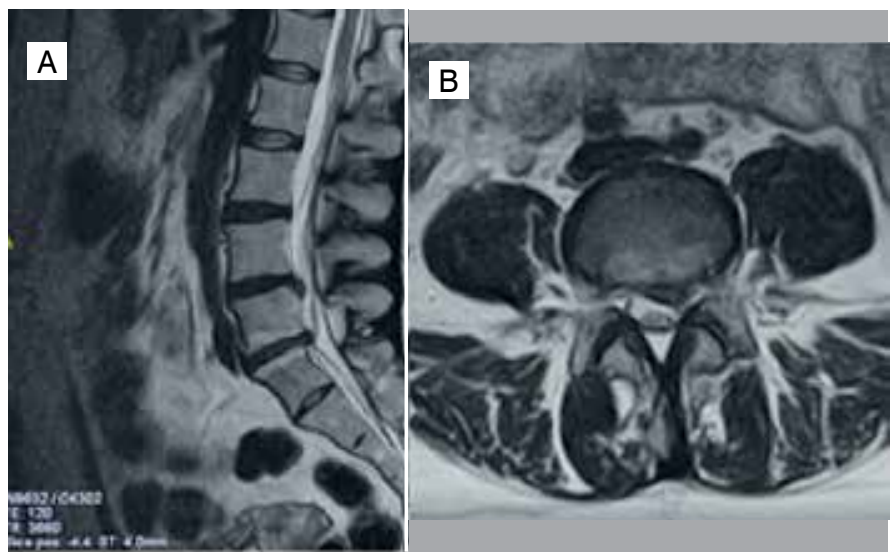

Figure 3. MRI, 13 months after surgery (L4-L5 LDH). Sagittal (A) and axial (B) planes.
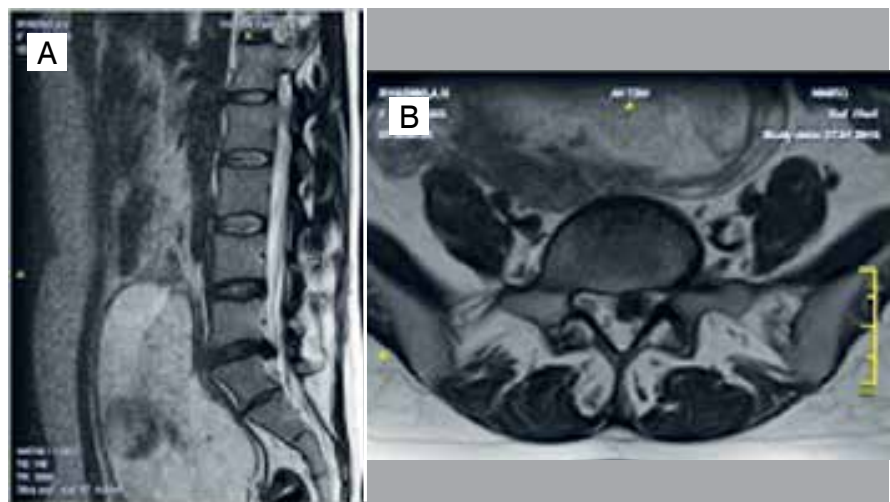

Figure 4. MRI before surgery (L5-S1 LDH). Sagittal (A) and axial (B) planes. 


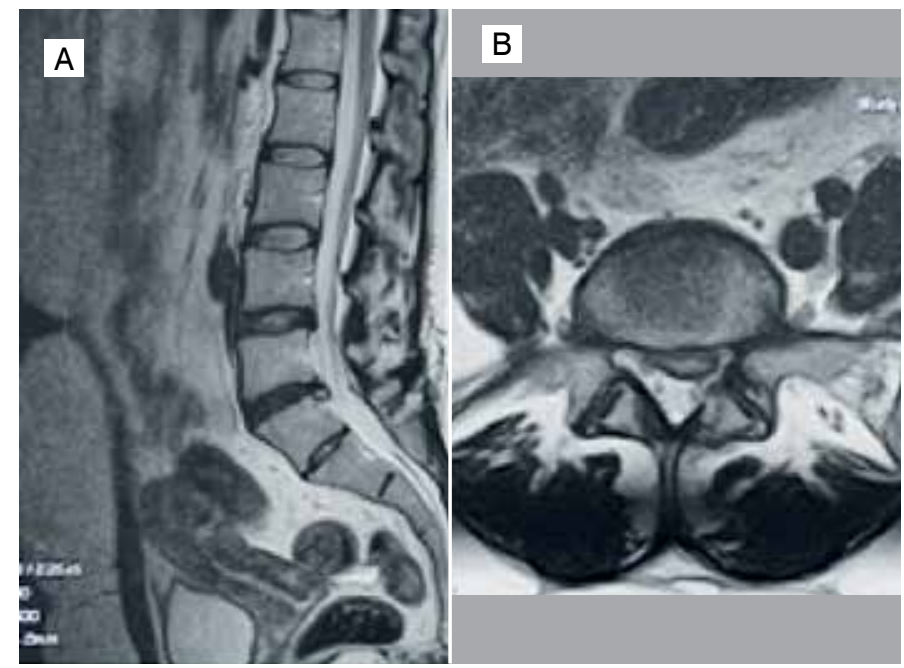

Figure 5. MRI, 10 months after surgery (L5-S1 recurrence LDH). Sagittal (A) and axial (B) planes.

other type of treatment, articles that did not relate to clinical studies, animal studies, articles not original, and duplicate studies. Among 157 potentially relevant articles, 125 were excluded based on the analysis of abstracts: 19 papers did not describe surgical treatment; 8 papers described only anesthesia; in 96 articles, either the patient was not pregnant, or the pregnant patient had no IVD herniation; and two articles did not describe the author's own clinical cases. After a full-text analysis of the remaining 42 articles, 12 articles were excluded as they were inconsistent with the purpose of the study.

Of four articles excluded after the full-text analysis, one described the effect of a previous discectomy on the course of back pain in pregnant females [2012 Beckmann]; in two papers, the need for surgery arose during delivery [2015 Jones and 2008 Chow]; in one paper, the need for surgery arose after delivery [1999 Timothy]. Thus, of the articles identified, 30 were eligible for inclusion; the data of 44 patients were extracted from the articles; along with the author's cases, the total number of patients was 46 .

The characteristics of all the identified patients are shown below Table 1. ${ }^{20-35}$

The median age of the females was 32.8 (IQR, 30-36) years. At least, twenty-three (50\%) females had a history of at least one pregnancy.

Lumbar IVD herniation at L4/L5, L3/L4, and L5/S1 levels was present in 20, 1, and 25 patients, respectively. IVD herniation at the L3/L4 level developed only in one (2.2\%) case. The L5/S1 (25 cases, $54.3 \%$ ) and L4/L5 (20 cases, 43.5\%) levels were more typical. In this case, L4/L5 lumbar IVD herniation was more typical of the 3rd trimester, while L5/S1 lumbar IVD herniation was more typical of the 2nd trimester.

Conservative treatment for a period of one day to five weeks failed to stop the symptoms in at least 29 cases.

Seven $(15.2 \%)$ patients underwent surgery in the first trimester of pregnancy; $25(54.3 \%)$ patients underwent surgery in the second trimester; and $14(30.4 \%)$ patients underwent surgery in the third trimester; in one (2.2\%) case, the authors did not specify the gestational age of surgery. Twenty-two (47.8\%) patients underwent surgery in the prone position; $8(17.4 \%)$ patients underwent surgery in the left lateral position; 4 (8.7\%) patients underwent surgery in the right lateral position; in $12(26.1 \%)$ patients, the position was not specified. In this case, the prone position was most typical of the second trimester; the left lateral position was equally used in both the second and third trimesters. In three $(6.5 \%)$ females, delivery was by Cesarean section, followed by a discectomy in the prone position. Among the cases in which anesthesia was specified, general and epidural anesthesias were distributed almost equally (19 and 14 cases, respectively). In 13 cases, the method of anesthesia was not described.
Among the reported cases, we found 4 unfavorable outcomes: one case of abortion due to the use of X-rays during examination and surgery; ${ }^{36}$ one case of miscarriage of one fetus in a biparous female after surgery; ${ }^{37}$ one case of postoperative wound infection; ${ }^{18}$ and one case of deep vein thrombosis of a lower limb in the postoperative period. ${ }^{38}$

In 19 cases (42.2\%), the authors noted persistent neurological symptoms at the end of the follow-up period, which manifested as both surgical complications and residual effects of the lesion.

\section{DISCUSSION}

Treatment of pregnant females with lumbar IVD herniation requires a multidisciplinary approach. The general principles of conservative treatment are similar to the management of the general population and include bed rest, physiotherapeutic procedures, administration of central analgesics and muscle relaxants, and epidural blockades. ${ }^{2,39}$ Restricted physical activity, a reduced vertical load, and a horizontal position with the lower limbs bent at the knee and hip joints helps to reduce pain as it decreases muscle spasms and lumbar lordosis. ${ }^{40}$ The capabilities of pharmacological therapy are limited during pregnancy because of toxic effects on the fetus. FDA category $A$ and $B$ drugs are recommended for use. ${ }^{41} \mathrm{NSAIDs}$ are not advisable during pregnancy because of their side effects. Paracetamol (non-narcotic analgesic, category B) and cyclobenzaprine (muscle relaxant, category B) are primarily used. ${ }^{42}$ Opioids may be used in the case of severe pain and failure of non-opioid analgesics. There are reports in the literature of the efficacy of epidural blockades with corticosteroids, but their prolonged use is associated with side effects on the fetus. ${ }^{43}$ In most cases, conservative treatment is effective; pain is relieved and has no adverse effect on the course of pregnancy.

Failure of conservative therapy for 6 weeks is an indication for routine examination to identify a substrate of the radicular symptoms. The scope of examination during pregnancy, as well as that of therapy, is somewhat limited due to a potential impact on the developing fetus. Radiographic examination in patients with degenerative IVD disease enables identification of the number and location of vertebrae, range of segment movement of the spinal motion segment, IVD height index, central angle of lordosis, etc. MSCT (CT) scans reveal the condition of bone tissue, anatomical location of the spinal structures, the presence of marginal osteophytes, bone defects, and the shape and condition of the facet joints and joint space. Currently, this is an integral part of preoperative examination. However, X-ray examination and intraoperative control are contraindicated during pregnancy due to the teratogenic effects on the fetus, ${ }^{44}$ which limits the choice of surgical treatment for pregnant patients.

$\mathrm{MRI}$ of the lumbar spine is the main technique for diagnosis of IVD herniation. Based on an MRI study, the type of herniation, Modic changes in adjacent parts of the vertebral bodies, Pfirrmann IVD degeneration grade, and Pathria and Grogan facet joint degeneration grade are determined. This diagnostic technique has no teratogenic properties, and it is not contraindicated for pregnant females; therefore, MRI is the only technique for objective diagnosis of a morphological substrate of pain in pregnant females. ${ }^{45}$

It should be noted that MRI findings play an important role in predicting the results of surgical treatment of lumbar IVD herniation patients ${ }^{39}$ and recurrent IVD herniation. ${ }^{46}$ In our 2 cases, the first patient had L5 retrolisthesis and Modic I type changes; the second patient also had $L 5$ retrolisthesis. These signs implied instability of the spinal motion segment. In our opinion, in the case of significant IVD bulging, the presence of direct and indirect signs of instability of the spinal motion segment, tendency of the adjacent vertebra to displacement, Pathria grade IV degeneration of the articular pair, and other factors, decompression-stabilization surgery $\left(360^{\circ}\right.$ interbody fusion) is advisable. We believe that this procedure is impossible in pregnant females because of limitations in the preoperative examination and intraoperative radiological monitoring 
Table 1. Summarized data of surgical treatment of lumbar disc herniation in pregnancy.

\begin{tabular}{|c|c|c|c|c|c|c|c|c|c|c|c|}
\hline & Age & $\begin{array}{c}\text { Pregnancy } / \\
\text { delivery }\end{array}$ & \begin{tabular}{|c|} 
Gestation \\
age when \\
symptoms \\
developed
\end{tabular} & Surgery time & $\begin{array}{c}\text { Cauda } \\
\text { equina } \\
\text { syndrome }\end{array}$ & $\begin{array}{c}\text { Conservative } \\
\text { treatment }\end{array}$ & $\begin{array}{c}\text { Anesthesia } \\
\text { type }\end{array}$ & $\begin{array}{l}\text { Surgical } \\
\text { position }\end{array}$ & Level, surgery & $\begin{array}{c}\text { If surgery } \\
\text { was after } \\
\text { delivery } \\
\text { (cesarean)? }\end{array}$ & $\begin{array}{l}\text { Residual } \\
\text { symptoms } \\
\text { within } \\
\text { follow-up }\end{array}$ \\
\hline $\begin{array}{c}1997 \\
\text { Garmel }\end{array}$ & 34 & G4 P2 & 9 weeks & $\mathrm{N} / \mathrm{A}$ & Yes & \begin{tabular}{|c|} 
bed rest, \\
ice packs, \\
lumbosacral \\
support, physical \\
therapy, and pain \\
medication \\
\end{tabular} & $\mathrm{N} / \mathrm{A}$ & N/A & L5-S1, LE and DE & No & No \\
\hline $\begin{array}{c}1995 \\
\text { LaBan }\end{array}$ & 29 & G1 P0 & 6 weeks & 11 weeks & No & 5 weeks & $\mathrm{N} / \mathrm{A}$ & $\mathrm{N} / \mathrm{A}$ & L5-S1, LE, DE & No & $\mathrm{N} / \mathrm{A}$ \\
\hline $\begin{array}{c}2008 \\
\text { Han }\end{array}$ & 30 & $\mathrm{~N} / \mathrm{A}$ & $\mathrm{N} / \mathrm{A}$ & 11 weeks & No & $\mathrm{N} / \mathrm{A}$ & Epidural & Prone & $\begin{array}{l}\text { L4-L5 and } \\
\text { L5-S1, posterior } \\
\text { lumbar interbody } \\
\text { fusion }\end{array}$ & No & No \\
\hline $\begin{array}{c}2008 \\
\mathrm{Han}\end{array}$ & 32 & $\mathrm{~N} / \mathrm{A}$ & $\mathrm{N} / \mathrm{A}$ & 11 weeks & No & $\mathrm{N} / \mathrm{A}$ & Epidural & Prone & $\begin{array}{l}\text { L4-L5, partial } \\
\text { hemiLE, DE }\end{array}$ & No & No \\
\hline $\begin{array}{l}2007 \\
\text { Curtin }\end{array}$ & 37 & G3 P2 & $<1$ week & 11 weeks & Yes & Yes & $\mathrm{N} / \mathrm{A}$ & $\mathrm{N} / \mathrm{A}$ & $\begin{array}{l}\text { L4-L5, lumbar DE } \\
\text { and nerve root } \\
\text { decompression }\end{array}$ & No & $\begin{array}{c}18 \text { months } \\
\text { - persistent } \\
\text { paraesthesia } \\
\text { down the back } \\
\text { of both legs and } \\
\text { anesthesia in the } \\
\text { saddle area }\end{array}$ \\
\hline $\begin{array}{l}2014 \\
\text { Speirs }\end{array}$ & 24 & G2 P2 & 15 weeks & 15 weeks & Yes & No & General & Prone & L5-S1, DE & No & No \\
\hline $\begin{array}{c}2008 \\
\operatorname{Han}\end{array}$ & 30 & $\mathrm{~N} / \mathrm{A}$ & $\mathrm{N} / \mathrm{A}$ & 15 weeks & No & N/A & Epidural & \begin{tabular}{|c} 
Right lateral \\
decubitus
\end{tabular} & $\begin{array}{l}\text { L5-S1, partial } \\
\text { hemiLE, DE }\end{array}$ & No & No \\
\hline Author's data & 31 & G1 P1 & 4 weeks & 16 weeks & No & Yes & $\begin{array}{c}\text { Epidural } \\
\text { anesthesia }\end{array}$ & Right lateral & $\begin{array}{c}\text { InterLE of L5-S1 on } \\
\text { the left, DE }\end{array}$ & No & $\begin{array}{l}10 \text { months - } \\
\text { reherniation } \\
\text { without need } \\
\text { for urgent } \\
\text { reoperation }\end{array}$ \\
\hline $\begin{array}{c}2001 \\
\text { Brown }\end{array}$ & 32 & GO PO & 13 weeks & 16 weeks & No & $\begin{array}{l}\text { Bed rest, } \\
\text { analgesics, } \\
\text { epidural steroid } \\
\text { injection }\end{array}$ & Epidural & Prone & $\begin{array}{c}\text { L5, right LE, partial } \\
\text { facetectomy, nerve } \\
\text { root decompression; } \\
\text { L5-S1, DE }\end{array}$ & No & $\begin{array}{c}10 \text { months } \\
\text { - a trace of } \\
\text { weakness in } \\
\text { the left peroneal } \\
\text { muscle group }\end{array}$ \\
\hline $\begin{array}{c}2004 \\
\text { Vougioukas } \\
\end{array}$ & 36 & $\mathrm{~N} / \mathrm{A}$ & $\mathrm{N} / \mathrm{A}$ & 18 weeks & No & $\mathrm{N} / \mathrm{A}$ & $\mathrm{N} / \mathrm{A}$ & $\mathrm{N} / \mathrm{A}$ & L5-S1, nucleotomy & No & No \\
\hline $\begin{array}{c}2006 \\
\text { Abou-Shameh }\end{array}$ & 34 & G2 P1 & 14 weeks & 19 weeks & No & $\begin{array}{l}4 \text { days - bed rest } \\
\text { routine analgesia }\end{array}$ & General & $\begin{array}{c}\text { Knee/ } \\
\text { elbow, with } \\
\text { simple side } \\
\text { supports }\end{array}$ & L4-5, right-sided DE & No & No \\
\hline $\begin{array}{c}2003 \\
\text { Reihani-Kermani }\end{array}$ & 26 & GO PO & $<16$ weeks & 20 weeks & Yes & $\begin{array}{l}4 \text { weeks - pain } \\
\text { medication, } \\
\text { exercise plan }\end{array}$ & N/A & N/A & $\begin{array}{c}\text { L4, LE; L3-L4, partial } \\
\text { DE }\end{array}$ & No & $\begin{array}{l}3 \text { months - foot } \\
\text { drop }\end{array}$ \\
\hline $\begin{array}{c}2008 \\
\text { Mohapatra }\end{array}$ & 30 & G1 P1 & $<17$ weeks & 20 weeks & Yes & Yes & General & Prone & $\begin{array}{c}\text { L5 and S1, LE; L5- } \\
\text { S1, DE }\end{array}$ & No & $\begin{array}{c}7 \text { month - } \\
\text { persistent } \\
\text { weakness in the } \\
\text { feet; incontinent } \\
\text { bladder and } \\
\text { bowel } \\
\end{array}$ \\
\hline $\begin{array}{l}2003 \\
\text { Iyilikçi }\end{array}$ & 31 & GO PO & $<16$ weeks & 20 weeks & No & N/A & \begin{tabular}{|c|} 
General \\
(tracheal \\
intubation)
\end{tabular} & Left lateral & L5-S1, DE & No & No \\
\hline $\begin{array}{c}2001 \\
\text { Brown }\end{array}$ & 31 & GO PO & 16 weeks & 20 weeks & No & \begin{tabular}{|c|}
3 weeks - bed \\
rest, two epidural \\
steroid injections, \\
oral steroids, \\
oxycodone, \\
acetaminophen \\
\end{tabular} & Epidural & Prone & $\begin{array}{l}\text { L5-S1, hemiLE, } \\
\text { partial facetectomy, } \\
\text { DE }\end{array}$ & No & $\begin{array}{l}15 \text { months - } \\
\text { minimal residual } \\
\text { hypoesthesia in } \\
\text { the right planta }\end{array}$ \\
\hline $\begin{array}{l}2011 \\
\text { Lee }\end{array}$ & 32 & $G ? P>0$ & 12 weeks & 20 weeks & No & 2 months & General & Left lateral & $\begin{array}{c}\text { L3, right extended } \\
\text { medial facetectomy } \\
\text { and adhesiolysis; } \\
\text { L4-L5, DE }\end{array}$ & No & No \\
\hline $\begin{array}{l}\text { Author's } \\
\text { experience }\end{array}$ & 36 & G1 P1 & $<17$ weeks & 20 weeks & Yes & Yes & Epidural & Left lateral & $\begin{array}{l}\text { InterLE of L5-S1 on } \\
\text { the right, DE }\end{array}$ & No & $\begin{array}{c}1 \text { year - } \\
\text { moderate } \\
\text { discomfort in } \\
\text { the right gluteal } \\
\text { region } \\
\end{array}$ \\
\hline $\begin{array}{c}1995 \\
\text { LaBan }\end{array}$ & 36 & G3 P1 & 20 weeks & 20 weeks & Yes & No & N/A & N/A & $\begin{array}{l}\text { L5-S1, lumbar LE } \\
\text { with DE }\end{array}$ & No & No \\
\hline $\begin{array}{l}2001 \\
\text { Brown }\end{array}$ & 41 & GO PO & 14 weeks & 20 weeks & Yes & Yes & Epidural & Prone & $\begin{array}{c}\text { L5-S1, hemiLE, } \\
\text { partial facetectomy, } \\
\text { DE }\end{array}$ & No & $\begin{array}{c}4 \text { years - } \\
\text { persistent } \\
\text { hypoesthesia on } \\
\text { the right side of } \\
\text { the perineum } \\
\text { necessitating } \\
\text { urethral dilatation } \\
\text { at 3-month } \\
\text { intervals; } \\
\text { urinary stress } \\
\text { incontinence; } \\
\text { constipation; 50\% } \\
\text { improvement in } \\
\text { bowel function }\end{array}$ \\
\hline
\end{tabular}




\begin{tabular}{|c|c|c|c|c|c|c|c|c|c|c|c|}
\hline & Age & $\begin{array}{c}\text { Pregnancy } / \\
\text { delivery }\end{array}$ & $\begin{array}{l}\text { Gestation } \\
\text { age when } \\
\text { symptoms } \\
\text { developed }\end{array}$ & Surgery time & $\begin{array}{c}\text { Cauda } \\
\text { equina } \\
\text { syndrome }\end{array}$ & $\begin{array}{c}\text { Conservative } \\
\text { treatment }\end{array}$ & $\begin{array}{c}\text { Anesthesia } \\
\text { type }\end{array}$ & $\begin{array}{l}\text { Surgical } \\
\text { position }\end{array}$ & Level, surgery & \begin{tabular}{|c|} 
If surgery \\
was after \\
delivery \\
(cesarean)?
\end{tabular} & $\begin{array}{c}\text { Residual } \\
\text { symptoms } \\
\text { within } \\
\text { follow-up } \\
\end{array}$ \\
\hline $\begin{array}{l}1997 \\
\text { Garmel }\end{array}$ & 29 & GO PO & 23 weeks & 24 weeks & Yes & $\begin{array}{c}2 \text { days pain } \\
\text { medication, } \\
\text { range-of-motion } \\
\text { exercises, and a } \\
\text { walker } \\
\end{array}$ & $\mathrm{N} / \mathrm{A}$ & N/A & L5-S1, DE & No & No \\
\hline $\begin{array}{l}2012 \\
\text { Hakan }\end{array}$ & 34 & $\mathrm{G} 2 \mathrm{P}$ ? & 25 weeks & 25 weeks & Yes & No & General & Prone & $\begin{array}{l}\text { L5-S1 right partial } \\
\text { hemilaminotomy, } \\
\text { microDE }\end{array}$ & No & $\begin{array}{c}\text { 6-month - bowel } \\
\text { and bladder } \\
\text { were nearly } \\
\text { normal, reduced } \\
\text { sensation in the } \\
\text { sacral area was } \\
\text { continuing } \\
\end{array}$ \\
\hline $\begin{array}{c}2008 \\
\mathrm{Han}\end{array}$ & 34 & N/A & N/A & 26 weeks & No & N/A & Epidural & $\begin{array}{c}\text { Right lateral } \\
\text { decubitus }\end{array}$ & $\begin{array}{c}\text { L4-L5, partial } \\
\text { hemiLE, DE }\end{array}$ & No & No \\
\hline $\begin{array}{l}2015 \\
\text { Martel }\end{array}$ & 27 & G1 P0 & 26 weeks & 28 weeks & No & $\begin{array}{c}6 \text { days of - } \\
\text { dexamethasone }\end{array}$ & General & Prone & $\begin{array}{c}\text { L4-L5, left hemiLE, } \\
\text { medial facetectomy, } \\
\text { microDE, } \\
\text { foraminotomy }\end{array}$ & No & No \\
\hline $\begin{array}{l}1997 \\
\text { Garmel }\end{array}$ & 28 & G5 P1 & 29 weeks & 30 weeks & Yes & $\begin{array}{l}4 \text { days of pain } \\
\text { medication }\end{array}$ & $\mathrm{N} / \mathrm{A}$ & N/A & L5-S1, LE and DE & No & $\begin{array}{c}3 \text { months - } \\
\text { minimal foot } \\
\text { numbness }\end{array}$ \\
\hline $\begin{array}{l}2007 \\
\text { Kim }\end{array}$ & 30 & GO PO & 22 weeks & 30 weeks & Yes & Yes & Regional & Prone & L4-L5, DE & No & $\begin{array}{l}3 \text { months - } \\
\text { persistent } \\
\text { hypoesthesia } \\
\text { and slightly } \\
\text { weakened } \\
\text { dorsiflexion on } \\
\text { the left side }\end{array}$ \\
\hline $\begin{array}{c}2008 \\
\mathrm{Han}\end{array}$ & 33 & N/A & N/A & 30 weeks & No & N/A & Epidural & \begin{tabular}{|l|} 
Left lateral \\
decubitus \\
\end{tabular} & $\begin{array}{l}\text { L4-L5, partial } \\
\text { hemiLE, DE }\end{array}$ & No & No \\
\hline $\begin{array}{c}2008 \\
\mathrm{Han}\end{array}$ & 30 & N/A & N/A & 32 weeks & No & N/A & Epidural & \begin{tabular}{|l|} 
Left lateral \\
decubitus \\
\end{tabular} & $\begin{array}{l}\text { L4-L5, partial } \\
\text { hemiLE, DE }\end{array}$ & No & No \\
\hline $\begin{array}{l}1998 \\
\text { Fahy }\end{array}$ & 32 & G3 P? & 30 weeks & 32 weeks & Yes & No & General & Prone & L4-L5, DE & No & $\begin{array}{c}7 \text { months - } \\
\text { slight residual } \\
\text { weakness in } \\
\text { the left anterior } \\
\text { tibialis } \\
\end{array}$ \\
\hline $\begin{array}{l}1998 \\
\text { Fahy }\end{array}$ & 31 & N/A & 29 weeks & 33 weeks & No & \begin{tabular}{|c|}
4 weeks - \\
analgesics, \\
oral morphine, \\
transcutaneous \\
nerve stimulation \\
\end{tabular} & General & Prone & L4-L5, left mini-DE & No & No \\
\hline $\begin{array}{c}2006 \\
\text { Kathirgamanathan } \\
\end{array}$ & 34 & GO PO & 33 weeks & 33 weeks & Yes & No & General & \begin{tabular}{|c} 
Left lateral \\
position \\
\end{tabular} & $\begin{array}{l}\angle 4-L 5, D E ; ~ L 5, \text { nerve } \\
\text { root decompression. }\end{array}$ & No & No \\
\hline $\begin{array}{l}2014 \\
\text { Ochi }\end{array}$ & 33 & N/A & 32 weeks & $\begin{array}{c}\text { Immediately } \\
\text { after CS at } \\
34^{\text {th }} \text { week }\end{array}$ & No & $\begin{array}{l}\text { Yes, } 2 \text { weeks } \\
\text { Patient received } \\
\text { physical } \\
\text { therapy and } \\
\text { acetaminophen } \\
\text { for pain relief } \\
\end{array}$ & Epidural & Prone & $\begin{array}{c}\text { (34 weeks) L4-L5, } \\
\text { left } D E ; \text {; (after } 6 \\
\text { days) L4-L5, right } \\
D E\end{array}$ & Yes & $\begin{array}{c}18 \text { months } \\
\text { - numbness } \\
\text { and slightly } \\
\text { weakened } \\
\text { dorsiflexion in the } \\
\text { left extremity }\end{array}$ \\
\hline $\begin{array}{c}2004 \\
\text { Vougioukas }\end{array}$ & 30 & GO PO & 35 weeks & 35 weeks & No & $\begin{array}{c}1 \text { day - } \\
\text { analgesics, } \\
\text { immobilization }\end{array}$ & $\mathrm{N} / \mathrm{A}$ & $\begin{array}{l}\text { Left lateral } \\
\text { decubitus }\end{array}$ & $\begin{array}{l}\text { L4-L5, partial left } \\
\text { DE, hemiLE }\end{array}$ & No & No \\
\hline $\begin{array}{l}2008 \\
\text { Gupta }\end{array}$ & 37 & G2 P1 & 35 weeks & \begin{tabular}{|c|} 
Immediately \\
after CS at \\
$35^{\text {th }}$ week \\
\end{tabular} & Yes & No & General & Prone & L5-S1, DE & Yes & No \\
\hline $\begin{array}{l}2015 \\
\text { Geftler }\end{array}$ & 33 & $\begin{array}{l}\text { Gmulti } \\
\text { Pmulti }\end{array}$ & 36 weeks & \begin{tabular}{|c|} 
Immediately \\
after CS at \\
$36^{\text {th }}$ week \\
\end{tabular} & Yes & No & General & Prone & \begin{tabular}{|c|} 
L4-L5 partial \\
Iaminoforaminotomy, \\
DE
\end{tabular} & Yes & No \\
\hline $\begin{array}{c}1999 \\
\text { Timothy }\end{array}$ & 37 & GO PO & 33 weeks & $\left|\begin{array}{c}4 \text { weeks after } \\
38 \text { weeks } \\
\text { uncomplicated } \\
\text { ventouse } \\
\text { delivery }\end{array}\right|$ & Yes & Yes & NA & NAA & L5-S1, DE & Yes & $\begin{array}{c}2 \text { years - gained } \\
\text { some anal } \\
\text { sphincter } \\
\text { control; still uses } \\
\text { intermittent } \\
\text { catheterization to } \\
\text { void urine; absent } \\
\text { sensation in the } \\
\text { perineal area with } \\
\text { associated sexual } \\
\text { dysfunction } \\
\end{array}$ \\
\hline
\end{tabular}

of the implant position in the spine..$^{36}$ Therefore, in the case of conservative therapy failure in pregnant females with IVD herniations, the only method of choice is decompression surgery without X-ray assistance (e.g., transforaminal sequestrectomy), which was used in our patients.

Surgery is not contraindicated in any period of pregnancy, ${ }^{20}$ but it requires maximum concentration of the surgical team. The patient's position on the operating table and the method of anesthesia used are of particular importance. In relation to the first, a review article by $\mathrm{H}$. Ardaillon et al. analyzed data from 17 authors from 27 cases of microdiscectomy in pregnant females, and demonstrated that the characteristics of patient position on the operating table depended on the gestational age. In patients with a gestational age of up to 25 weeks, the position on the operating table did not differ from that in the general population. At more than 34 weeks, they recommend Cesarean section followed by microdiscectomy during a single anesthesia. Difficulties may arise at a gestational age of 25-34 weeks. In this period, the left side position is recommended, to prevent damage to the fetus and low blood pressure due to compression of the inferior vena cava. ${ }^{18}$ 
The indications for elective or urgent surgery of pregnant lumbar IVD herniation patients do not differ from those for other patients. In the case of intractable radicular symptoms, routine surgical procedures are used; urgent surgery is indicated for neurological deficit progression and cauda equina syndrome.

Some authors suggest surgical treatment of spine pathology after childbirth. For example, Timothy et al. described surgery for a herniated IVD, which was performed 4 weeks after childbirth. However, untimely treatment of cauda equina syndrome (which occurred in one patient in our case) leads to severe neurological complications and disability of the patient. In a review of the literature, we found two cases describing untimely diagnosis of cauda equina syndrome in pregnant females. A neurological deficit persisted in the patients for a follow-up period of up to 24 months. ${ }^{10,47}$ Chow et al. presented a case of cauda equina syndrome in a pregnant patient after Cesarean section. The pregnant patient at a gestational age of 36 weeks presented with pain and numbness in the right lower limb and slight incontinence. The patient also suffered from diabetes and obesity. Given the neurological deficit and concomitant diseases, Cesarean section was performed. The patient developed persistent dysfunction of the pelvic organs in the form of bladder and bowel incontinence $36 \mathrm{~h}$ after surgery. Also, numbness in the perineum was present in the neurological status. MRI of the lumbar spine showed a sequestered L5-S1 IVD with caudal displacement. The patient underwent urgent surgery, including S1 laminectomy and removal of IVD herniation. Bladder incontinence persisted three weeks after surgery. ${ }^{13}$ In our opinion, $\mathrm{MRI}$ of the lumbar spine and further treatment, with allowance for the results of the examination at admission, when the radicular syndrome first developed, might prevent the development of a persistent neurological deficit in the described cases. This publication demonstrates the importance of timely diagnosis and surgical treatment, and we agree with the authors that cauda equina syndrome requires urgent surgery, and its diagnosis in pregnant females requires a thorough examination, including the patient's history, and differential diagnosis because of potential urogenital disorders. In the present review, an approach combining Cesarean section and removal of IVD herniation during a single anesthesia is used in three cases $8,19,48$ which, according to the authors, is an optimal treatment for pregnant IVD herniation patients. It should also be noted that Cesarean section can only be used in late pregnancy, while the waiting until natural delivery can lead to severe neurological deficit and (or) pain syndrome.

One of the main components of intraoperative management of pregnant patients is monitoring of the cardiac fetal activity. According to some authors, intraoperative monitoring of fetal heartbeat at a gestational age of up to 20 weeks is not indicated; starting with the 23rd week, this procedure is mandatory; monitoring between 20 and 23 weeks is controversial. ${ }^{49}$ Given the influence of general anesthesia on fetal heart activity, as well as inadequate development of the fetal cardiovascular system, the data obtained at up to 28 weeks of gestation are insufficient and unreliable. We operated on pregnant females at a gestation of less than 20 weeks, and we considered it unreasonable to intraoperatively monitor fetal heartbeats. ${ }^{49-51}$ Many physiological parameters are disturbed during pregnancy, particularly by the end of the second trimester. The stressful condition before surgery also negatively affects the functional state of the pregnant patient. During pregnancy, there is an increase in the volume of circulating blood, an acceleration of glomerular filtration, and an increase in the tissue oxygen demand with a simultaneous reduction in the functional residual capacity of the lungs. These changes require competent management of anesthesia to avoid potential episodes of hypoxemia, hypotension, acidosis, hypo- or hyperventilation, and other changes in metabolism and pharmacodynamics. ${ }^{52}$ A significant change in minute ventilation of the lungs and functional residual capacity in the last two trimesters of pregnancy will lead to an increase in the pregnant female's sensitivity to anesthetics. ${ }^{53}$
Epidural and general anesthesias are not contraindicated in any period of pregnancy. ${ }^{9}$ In the literature, there is no evidence of the effect of anesthesia during pregnancy on congenital anomalies, premature birth, and perinatal mortality. ${ }^{53,54}$ The main goals of anesthetic care during pregnancy are to ensure adequate blood pressure, carefully monitor respiratory function, and prevent hypertonia of the sympathetic nervous system, fetal asphyxia, and premature birth. Epidural anesthesia may be more preferable than general anesthesia for reducing the risk of pulmonary aspiration and unsuccessful intubation, and may also minimize the effect of medications on the fetus. Some authors prefer general anesthesia because of its minimal hypotensive action and rapid, and reliable effect.9,54

In the literature analyzed, intraoperative complications were not documented. In two cases, abortion was reported. Han et al. operated on a 30-year-old pregnant female at 11 weeks gestation. Due to the large size of the IVD herniation, the patient underwent transpedicular fixation with posterior interbody fusion. During examination and surgery, X-ray was used; for this reason, the patient underwent termination of pregnancy after surgery because of a high risk of fetal anomalies. ${ }^{36}$ Speirs et al. operated on a pregnant patient at 15 weeks of gestation for lumbar IVD herniations; decompression surgery was performed, with good clinical results. According to the postoperative ultrasound, there were no fetal abnormalities. But later, it turned out that the pregnant patient was carrying twins, and a spontaneous miscarriage of one fetus occurred. The second fetus developed normally, and the patient gave birth to a healthy child at 39 weeks. ${ }^{37}$ In this case, it is difficult to establish the degree of influence of the surgery on the course of the pregnancy because according to the ultrasound, the pregnancy was preserved immediately after surgery. In pregnant females, as in the general population, complications can develop in the postoperative period. The rate of complications in pregnant patients is no different from that of the general population. Ardaillon et al. detected infection of a postoperative wound after microdiscectomy in a pregnant patient. A 39-year-old patient at 17 weeks of gestation underwent surgery under general anesthesia in the prone position. On the 14th day after surgery, wound dehiscence was revealed; a bacteriological study of wound fluid detected the growth of Staphylococcus aureus. A re-operation was performed also in the prone position, with revision, sanitation of the wound, and resuturing. Subsequent pregnancy and delivery were on time, and without complications. ${ }^{18}$ Garmel et al. described the development of deep vein thrombosis after microdiscectomy in a 34-year-old female at 9 weeks of gestation. The patient underwent anticoagulant therapy with a positive effect; delivery was on time and without complications. ${ }^{37}$ In pregnant females with IVD herniation, complications with persistent disabling effects arise, as indicated above, in the case of untimely diagnosis of cauda equina syndrome.

There are no data in the literature on the rate of recurrent IVD herniation after a microdiscectomy performed during pregnancy. Ochi et al. described a case of recurrent IVD herniation in the early postoperative period. A patient at 34 weeks gestation underwent a L4/L5 microdiscectomy on the left immediately after Cesarean section. Surgery was performed under epidural anesthesia, in the prone position. Radicular symptoms on the contralateral side developed in the early postoperative period. MRI of the lumbar spine revealed IVD herniation at L4/L5 on the right. Six days after surgery, the patient underwent re-operation, and the L4/L5 herniated IVD on the right was removed. ${ }^{50}$ In our series of two patients, one had recurrence of pain caused by IVD herniation at L4/L5 on the left 13 months after surgery (surgery at L5/S1 on the right). MRI of the lumbar spine in the second patient revealed asymptomatic recurrent IVD herniation at the operated level, on the ipsilateral side, 10 months after surgery. Given the lack of clinical manifestations of IVD herniation, the patient follow-up was continued. According to the MRI findings, this patient was initially detected as having $L 5$ retrolisthesis and, if additional data (radiography) had been available, our plan for surgical treatment 
might have been changed; perhaps, we would have suggested that the patient undergo herniated IVD removal with subsequent screw and interbody fusion; however, we refused preoperative radiography of the lumbar spine and intraoperative $\mathrm{X}$-ray due to potential harm to the fetus.

In our patients, a traditional microdiscectomy was performed, without any surgical care for the fetus. The patients gave birth to healthy children.

Endoscopic removal of IVD herniation in pregnant females has been reported in the literature. A paper by Eichholz et al. presented two cases of endoscopic microdiscectomy in pregnant patients. In the first case, surgery was performed at 15 weeks of gestation in the prone position on the Wilson stand. In the second case, surgery was performed at 27 weeks of gestation in the right lateral position, with intraoperative fetal monitoring. In both cases, the result of surgery was favorable. According to the authors, the advantages of this technique include minimal postoperative pain, less use of analgesics, and faster recovery. ${ }^{11} \mathrm{Kim}$ et al. also described a case of endoscopic microdiscectomy in a pregnant female with cauda equina syndrome. Emergency surgery was performed at 30 weeks of gestation, without complications. Intraoperative monitoring of the fetal heart activity was carried out. In the early postoperative period, pain relief was achieved in the lower limbs. A follow-up examination after
3 months revealed hypoesthesia and slight weakness of the left foot dorsiflexion. ${ }^{12}$ However, the endoscopic surgical technique is only a method of intraoperative visualization, and the use of endoscopic transforaminal sequestrectomy requires mainly $X$-ray intraoperative control, which limits its use in these patients.

\section{CONCLUSIONS}

Decompression surgery in pregnant females with lumbar IVD herniation, when adhering to the multidisciplinary approach, is an effective and safe procedure for both the mother and the fetus. The diagnosis of spinal motion segment pathology and its surgical treatment in pregnant patients are characterized by a number of features and limitations and, in some cases, cannot be cured radically during pregnancy. If a neurological deficit caused by IVD herniation develops, decompression surgery should be performed as soon as possible; Cesarean section and removal of a herniated IVD can be performed under a single anesthesia. Waiting for natural delivery is inadvisable.

All authors declare no potential conflict of interest related to this article.

CONTRIBUTION OF THE AUTHORS: Each author made significant individual contributions to this manuscript. AVK (0000-0002-2570-3066) $(0000-0002-4744-4077)^{*}$ and AVP $(0000-0002-4588-428 X)^{*}$ were the main contributors in the drafting of the manuscript. AVK, AJS and AVP performed the surgery, followed up the patients and gathered clinical data. AAA (0000-0002-7307-4524)* and AVM (0000-0002-6711-3822)* evaluated the data from the statistical analysis. AJS, AVK and VAB (0000-0003-4349-7101) performed the literature search and review of the manuscript, and contributed to the intellectual concept of the study. ${ }^{*}$ ORCID (Open Researcher and Contributor ID).

\section{REFERENCES}

1. Ansari NN, Hasson S, Naghdi S, Keyhani S, Jalaie S. Low back pain during pregnancy in Iranian women: prevalence and risk factors. Physiother Theory Pract. 2010;26(1):40-8.

2. Bhardwaj A, Nagandla K. Musculoskeletal symptoms and orthopaedic complications in pregnancy: pathophysiology, diagnostic approaches and modern management. Postgrad Med J. 2014;90(1066):450-60.

3. Ritchie JR. Orthopedic considerations during pregnancy. Clin Obstet Gynecol. 2003:46(2):456-66

4. MacLennan AH, Nicolson R, Green RC, Bath M. Serum relaxin and pelvic pain of pregnancy. Lancet. 1986;2(8501):243-5.

5. Marnach ML, Ramin KD, Ramsey PS, Song SW, Stensland JJ, An KN. Characterization of the relationship between joint laxity and maternal hormones in pregnancy. Obstet Gynecol. 2003;101(2):331-5.

6. Ostgaard HC, Anderson GB, Karlson K. Prevalence of back pain in pregnancy. Spine (Phila Pa 1976). 1991;16(5):549-52

7. LaBan MM, Viola S, Williams DA, Wang AM. Magnetic resonance imaging of the lumbar herniated disc in pregnancy. Am J Phys Med Rehabil. 1995;74(1):59-61.

8. Aldabe D, Ribeiro D, Milosavljevic S, Dawn Bussey M. Pregnancy-related pelvic girdle pain and its relationship with relaxin levels during pregnancy: a systematic review. Eur Spine J. 2012;21(9):1769-76.

9. Iyilikc IL, Erbayraktar S, Tural AN, Celik M, Sannav S. Anesthetic management of lumbar discectomy in a pregnant patient. J Anesth. 2004;18(1):45-7.

10. Mohapatra RN, Patra RK. Cauda Equina Syndrome in Pregnancy Due to Disc Prolapse. JIACM. 2008;9(2):140-2.

11. Eichholz MK, O’Toole J, Eichholz AC, Fessler R. Minimally invasive lumbar microendoscopic discectomy in the pregnant patient: Report of two cases. Pan Arab Journal of
Neurosurgery. 2010;14(1)

12. Kim HS, Kim SW, Lee SM, Shin H. Endoscopic discectomy for the cauda equina syndrome during third trimester of pregnancy. J Korean Neurosurg Soc. 2007;42(5):419-20.

13. Chow J, Chen K, Sen R, Stanford R, Lowe S. Cauda equina syndrome post-caesarean section. Aust N Z J Obstet Gynaecol. 2008;48(2):218-20

14. Gupta P, Gurumurthy M, Gangineni K, Anarabasu A, Keay SD. Acute presentation of cauda equina syndrome in the third trimester of pregnancy. Eur J Obstet Gynecol Reprod Biol. 2008:140(2):279-81.

15. Abou-Shameh MA, Dosani D, Gopal S, McLaren AG. Lumbar discectomy in pregnancy. Int J Gynaecol Obstet. 2006;92(2):167-9.

16. Hayakawa K, Mizutani J, Suzuki N, Haas C, Kondo A, Otsuka S et al. Surgical Management of the Pregnant Patient With Lumbar Disc Herniation in the Latter Stage of the SecondTrimester. Spine (Phila Pa 1976). 2017;42(3):E186-9.

17. Reihani-Kermani $\mathrm{H}$. Cauda equina syndrome in pregnancy. Archives of Iranian medicine. 2003;6(2):146-8.

18. Ardaillon $\mathrm{H}$, LavivY, Arle JE, Kasper EM. Lumbar disk herniation during pregnancy: a review on general management and timing of surgery. Acta Neurochir (Wien). 2017.

19. Di Martino A, Russo F, Denaro L, DenaroV. How to treat lumbar disc herniation in pregnancy? A systematic review on current standards. Eur Spine J. 2017;26(Suppl 4):496-504.

20. Brown MD, Levi AD. Surgery for lumbar disc herniation during pregnancy. Spine (Phila Pa 1976).2001;26(4):440-3.

21. Speirs $E$, Wiles $M$, Bacon $A$, Radley S. Positioning a proned patient with cauda equina syndrome who presents at 15 weeks gestation: a case report. F1000Res. 2014;3:117.

22. Al-areibi A, Coveney L, Singh S, Katsiris S. Case report: anesthetic management for sequential Cesarean delivery and laminectomy. Can J Anaesth. 2007;54(6):471-4. 
23. Kathirgamanathan A, Jardine AD, Levy DM, Grevitt MP. Lumbar disc surgery in the third trimester - with the fetus in utero. Int J Obstet Anesth 2006;15(2):181-2.

24. Vougioukas VI, Kyroussis G, Gläsker S, Tatagiba M, Scheufler KM. Neurosurgical interventions during pregnancy and the puerperium: clinical considerations and management. Acta Neurochir (Wien). 2004;146(12):1287-91.

25. Hakan T. Lumbar disk herniation presented with cauda equina syndrome in a pregnant woman. J Neurosci Rural Pract. 2012;3(2):197-9.

26. Martel CG, Volpi-Abadie J, Ural K. Anesthetic management of the parturient for lumbar disc surgery in the prone position. Ochsner J. 2015;15(3):259-61.

27. Fahy UM, Oni M, Findlay D, Sell P. Surgical management of herniated lumbar disc in pregnancy. J Obstet Gynaecol. 1998;18(6):544-5.

28. O'Laughlin SJ, Kokosinski E. Cauda equina syndrome in a pregnant woman referred to physical therapy for low back pain. J Orthop Sports Phys Ther. 2008;38(11):721.

29. Brown MD, Brookfield KF. Lumbar disc excision and cesarean delivery during the same anesthesia. A case report. J Bone Joint Surg Am. 2004;86-A(9):2030-2.

30. Kanas M, Kunzle H, Martins DE, Kirsch LA, Puertas EB, Wajchenberg M. Diskectomy during Pregnancy: Case Report and Review of the Literature. Global Spine J. 2015;5(2):130-4.

31. Ashkan K, Casey AT, Powell M, Crockard HA. Back pain during pregnancy and after childbirth: an unusual cause not to miss. J R Soc Med. 1998;91(2):88-90.

32. Lee JM, Han IH, Moon SH, Choi BK. Surgery for Recurrent Lumbar Disc Herniation During Pregnancy: A Case Report. Korean J Spine. 2011;8(4):304-6.

33. Anton Capitan B, MalillosTóran M. The cauda equina syndrome in pregnant woman with a massive disc herniation. Rev Esp Cir Ortop Traumatol. 2017;61(1):63-5.

34. Jones CS, Patel S, Griffthis-Jones W, Stokes OM. Presentation of cauda equina syndrome during labour. BMJ Case Rep. 2015;18;2015.

35. Naimer SA, Carni A. [Safe quadruplet gestation following peripartum discectomy for massive disc prolapse]. Harefuah. 2014;153(1):6-7.

36. Ray JG, Vermeulen MJ, Bharatha A, MontaneraWJ, Park AL. Association Between MRI EXposure During Pregnancy and Fetal and Childhood Outcomes. JAMA. 2016;316(9):952-61.

37. Garmel SH, Guzelian GA, D'Alton JG, D'Alton ME. Lumbar disk disease in pregnancy. Obstet Gynecol. 1997;89(5 Pt 2):821-2.

38. Han IH, Kuh SU, Kim JH, Chin DK, Kim KS, Yoon YS et al. Clinical approach and surgical strategy for spinal diseases in pregnant women: a report of ten cases. Spine (Phila Pa 1976). 2008;33(17):E614-9.
39. Alaeldin A, Darwich, MD, Sudhir A. Diwan, MD. Management of back pain in pregnancy. Techniques in Regional Anesthesia and Pain Management. 2009;13:251-4.

40. Jacobson H. Protecting the back during pregnancy. AAOHN J. 1991;39:286-91.

41. Briggs GC, Freeman RK, Yaffe SJ. A Reference Guide to Fetal and Neonatal Risk: Drugs in Pregnancy and Lactation (ed 7). Philadelphia: Lippincott Williams \&Wilkins, 1990.

42. Borg-Stein J, Dugan S, Gruber J. Musculoskeletal aspects of pregnancy. Am J Phys Med Rehabil. 2005;84(3):180-92.

43. Mariotti V, Marconi AM, Pardi G. Undesired effects of steroids during pregnancy. J Matern Fetal Neonatal Med. 2004;16 (Suppl 2):5-7.

44. De Santis M, Di Gianantonio E, Straface G, Cavaliere AF, Caruso A, Schiavon F et al. Ionizing radiations in pregnancy and teratogenesis: a review of literature. Reprod Toxicol. 2005;20(3):323-9.

45. Goodman S. Anesthesia for nonobstetric surgery in the pregnant patient. Semin Perinatol. 2002;26(2):136-45.

46. Belykh E, Krutko AV, Baykov ES, Giers MB, Preul MC, ByvaltsevVA. Preoperative estimation of disc herniation recurrence after microdiscectomy: predictive value of a multivariate model based on radiographic parameters. Spine J. 2016;17(3):390-400.

47. Timothy J, Anthony R, Tyagi A, Porter D, van Hille PT. A case of delayed diagnosis of the cauda equina syndrome in pregnancy. Aust N Z J Obstet Gynaecol. 1999;39(2):260-1.

48. Geftler A, Sasson A, Shelef I, Perry ZH, Atar D. Cauda equina syndrome in a 36 week gravida patient. Isr Med Assoc J. 2015;17(8):522-3.

49. Katz JD, Hook $R$, Barash PG. Fetal heart rate monitoring in pregnant patients undergoing surgery. Am J Obstet Gynecol. 1976;125(2):267-9.

50. Ochi H, Ohno R, Kubota M, Hanyu R, Sakai K, Sugawara Y et al. Case report: The operation for the lumbar disk herniation just after cesarean delivery in the third trimester of pregnancy. Int J Surg Case Rep. 2014;5(12):1178-82.

51. Biehl DR. Foetal monitoring during surgery unrelated to pregnancy. Can Anaesth Soc J. 1985;32(5):455-9.

52. Chestnut DH. Nonobstetric Surgery During Pregnancy. Yearb Anesthesiol Pain Manag. 2012:335-6

53. Glosten B. Anesthesia for obstetrics. In: Miller RD (ed) Anesthesia. New York: Churchill Livingstone; 2000. p. 202568.

54. Morgan GE, Mikhail SM, Murray JM. Clinical anesthesiology. New York: McGraw-Hill; 2002. p. 819-846. 